\title{
ANTIOXIDANT ACTIVITY AND TOTAL PHENOLIC CONTENT OF DATE PALMS SYRUP (Phoenix dactylifera $\mathrm{L}$ )
}

\author{
Yetri Elisya, Harpolia Cartika, Anindita Rizkiana \\ Jurusan Farmasi, Poltekkes Jakarta II, Percetakan Negara No.23, Jakarta, 10560 \\ E-mail:yetri.elisya@gmail.com, harpoliacartika@gmail.com
}

\begin{abstract}
Palm date fruits (Phoenix dactylifera L) have been used for medical treatment, one of the medical purpose as antioxidant, which is the coumpound for free radical scavenging. In this study used palm juice makes with non sentrifuged method by grounds 200 grams of palm fruit with $20 \mathrm{ml}$ of aquadest and store in room temperature. For date palm syrup used in this study were from certain brand distributed on the market. Antioxidant activity was testing by using DPPH method and determined by spectrophotometry Uv-Vis in wavelength $517 \mathrm{~nm}$, and Total Phenolic Content was testing by Folin Ciocalteu method and determined by spectrophotometry Uv-Vis in wavelength 774nm. 11 sample of date palm syrup was sampling by purposive sampling methods and then got 2 sample to tested. Date Palm Juice were made by Non Cetrifuged methods. All sample were tested antioxidant activity using DPPH and Total Phenolic Content using Folin Ciocalteu. This study obtained that best operating time for all sample in antioxidant activity is 30 minutes with the highest point is Date Palm Juice $91,54 \%$, Sample $\mathrm{X}$ for $86,93 \%$ and Sampel Y 89,92\%. There was a linear correlation between with the result Total Phenolic Content for Date Palm Juice 9,25 mgGAE/g, Sample X 4,13 mgGAE/g and Sampel Y 4,28 mgGAE/g. Date Palm Juice and Date Palm Syrup could scavenge free radical DPPH in huge concentration and contain phenolic compound.
\end{abstract}

Key word :Date Palm Syrup, antioxidant, DPPH, total phenolic, Folin Ciocalteu, spectrophotomery Uv-vis.

\section{UJI AKTIVITAS ANTIOKSIDAN DAN TOTAL FENOL SARI BUAH KURMA (Phoenix dactylifera L)}

\begin{abstract}
ABSTRAK
Buah Kurma (Phoenix dactylifera L) mengandung maanfaat untuk kesehatan,salah satunya adalah antioksidan yaitu senyawa yang dapat meredam radikal bebas. Pada penelitian ini digunakan Jus buah kurma buatan sendiri dengan menghaluskan 200 gram buah kurma ditambahkan $20 \mathrm{ml}$ aquadest kemudian di simpan pada suhu ruang dan Sari Buah Kurma dari merek tertentu yang berada di pasaran. Penentuan aktivitas antioksidan menggunakan metode DPPH yang diukur absorbansinya dengan spektrofotmetri UV-Vis pada panjang gelombang $517 \mathrm{~nm}$ di menit ke-5, ke-30 dan ke-60. Sementara Total Fenol dengan metode Folin Ciocalteu yang diukur absorbansinya dengan spektrofotommetri UV- Vis pada panjang gelombang $774 \mathrm{~nm}$. 11 merek Sari Buah kurma yang didapat diambil 2 sampel ( $\mathrm{X}$ dan $\mathrm{Y}$ ) secara purposive samplingsementara Jus Buah Kurma dibuat dengan metode Non Sentrifugasi. Sampel kemudian diuji aktivitas antioksidan menggunakan metode DPPH (1,1-difenil-2-pikrilhidrazil) dan total fenol menggunakan metode Folin Ciocalteu. Operating timeterbaik untuk ketiga sampel adalah menit ke - 30 dengan persen peredaman tertinggi Jus Buah Kurma yaitu 91,54\%. Sampel X 86,93\% dan sampel Y 89,92\%. Dan berbanding lurus dengan Total Fenol pada Jus Buah Kurma yaitu 9,25 mgGAE/g. Sampel X 4,13 mgGAE/g, dan Sampel Y 4,28 mgGAE/g. Jus Buah Kurma dan Sari Buah Kurma dapat meredam radikal bebas DPPH pada konsentrasi yang besar serta memiliki nilai total fenolik.
\end{abstract}

Kata Kunci: Sari buah kurma, antioksidan, DPPH, total fenol, Folin Ciocalteu, spektrofotometri Uv-Vis 


\section{PENDAHULUAN}

Sebagian besar penyakit diawali oleh adanya reaksi oksidasi yang berlebihan dalam tubuh. Reaksi oksidasi tersebut dapat memicu terbentuknya radikal bebas yang sangat aktif, sehingga dapat merusak struktur serta fungsi sel (1). Salah satu senyawa kimia yang mampu menghambat penuaan dan mengatasi berbagai macam penyakit degeneratif diatas yang diakibatkan oleh radikal bebas, dan dapat mencegah proses oksidasi atau menghambat radikal bebas adalah senyawa antioksidan $^{2}$. Senyawa antioksidan adalah senyawa polifenol yang mengandung beberapa gugus fenolik. Polifenol alami memiliki banyak aktivitas biologi, khususnya sebagai antioksidan.(2) Senyawa polifenol dengan gugus hidroksil yang terikat pada cincin aromatik merupakan senyawa yang efektif sebagai antioksidan karena senyawa tersebut mampu meredam radikal bebas dengan cara memberikan atom hidrogen (donor proton) dari gugus hidroksil kepada radikal bebas.(3)

Nilai aktivitas antioksidan biasa dinyatakan dalam nilai \% Inhibisi dan $\mathrm{IC}_{50}$. $\%$ Inhibisi adalah presentase suatu sampel yang dapat meredam radikal bebas DPPH. (4) Sementara nilai $\mathrm{IC}_{50}$ adalah konsentrasi ekstrak yang dapat meredam 50\% konsentrasi radikal bebas DPPH. (4)

Salah satu tanaman yang memiliki senyawa antioksidan dan diindikasi dapat meredam radikal bebas adalah kurma (Phoenix dactylifera L.). (2). Hasil penapisan fitokimia menyebutkan bahwa buah kurma memiliki kandungan polifenol seperti flavonoid, senyawa prosianidin dan antosianidin. (2). Pada penelitian yang telah dilakukan di Arab Saudi, aktivitas antioksidan ekstrak etanol $80 \%$ buah kurma dapat memberikan nilai IC50 sebesar 84,92 ppm dan menunjukkan angka 600,3 mg / $100 \mathrm{mg}$ d-cathecin. (5) Ini berarti bahwa sari buah kurma merupakan zat yang berkhasiat antioksidan kuat.
Buah kurma dapat diolah menjadi beberapa produk makanan ataupun minuman, seperti kurma kering, manisan kurma, pasta kurma, selai kurma, acar kurma, margarin kurma, cokelat kurma, bahkan saat ini banyak beredar sari buah kurma di pasaran. Namun dengan perkembangan olahan buah kurma ini, sediaan yang paling banyak diminati adalah sari buah kurma karena dinilai praktis dalam segi kemasan. Pembuatan sari buah kurma dimulai dengan memasukan beberapa gram buah kurma segar kedalam wadah kemudian ditambahkan air mendidih dan kemudian diaduk secara teratur sampai bagian biji buah kurma terlepas dan terpisah. Kemudian cairan yang dihasilkan dipisahkan dengan ampasnya untuk dilanjutkan untuk dimasak selama 13 jam. Untuk produk akhir beberapa produsen menambahkan gula tambahan seperti sukrosa dan glukosa. (6)

Seperti yang telah dijelaskan diatas, bahwa proses pembuatan sari buah kurma mengalami proses penambahan air mendidih yaitu mencapai suhu $100^{\circ} \mathrm{C}$, maka akan terjadi perubahan dari kelarutan senyawa fenolik di dalam sari buah kurma. Pada umumnya kelarutan zat aktif yang didapatkan dari tanaman akan bertambah besar dengan bertambahnya suhu, namun senyawa seperti flavonid, tanin dan fenol dapat rusak pada suhu diatas $50^{\circ} \mathrm{C}$ dengan mengalami perubahan struktur.(7)

Hal ini yang menjadi latar belakang penulis untuk melakukan penelitian uji penetapan kadar fenolik total pada jus buah kurma non sentrifugasi dan sari buah kurma dengan metode Folin Ciocalteu serta aktivitas antioksidan pada sari buah kurma dengan metode DPPH.

\section{METODE PENELITIAN}

Penelitian ini dilakukan menggunakan metode eksperimental yaitu dengan menampilkan data data setelah adanya perlakuan terhadap objek.Produk sari buah kurma diperoleh dengan studi 
pendahuluan.Teknik pengambilan sampel dilakukan secara purposive sampling, yaitu sampel sari buah kurma ditentukan atas dasar tujuan dan pertimbangan penulis dilihat dari kriteria inklusi dan eksklusi.

Kriteria inklusi dalam penelitian ini adalah:

a. Sari buah kurma dengan komposisi buah kurma dan air serta gula, tidak ada bahan tambahan lainnya (khususnya simplisa lain)

b. Sari buah kurma yang memiliki registrasi dari BPOM.

c. Sari buah kurma yang memiliki expired date tahun 2018.

Sedangkan kriteria eksklusi pada penelitian ini adalah :

a. Sari buah kurma dengan komposisi buah kurma dan tambahan bahan lain.

b. Sari buah kurma tanpa nomor registrasi dari BPOM.

c. Sari buah kurma yang memiliki expired date tahun 2017,2019,2020.

\section{Prosedur Penelitian}

\section{Persiapan jus buah kurma}

2gram buah kurma yang sudah dihancurkan menggunakan blender kemudian ditambahkan $20 \mathrm{ml}$ aquadest. Campuran ini kemudian diaduk selama 20 menit. Kemudian dikumpulkan dan disimpan dalam suhu ruang.(8)

\section{Pengambilan sampel sari buah kurma di toko wilayah Otista Jakarta Timur}

Pengambilan sampel sari buah kurma di toko barang impor dari Arab Saudi di wilayah Otista Jakarta Timur dengan cara melakukan studi pendahuluan berdasarkan seluruh merek sari buah kurma yang diperjualbelikan. Sampel sari buah kurma yang diambil adalah sampel yang memenuhi kriteria inklusi yang ditentukan peneliti. Dari 11 sampel sari buah kurma, 6 sampel mengandung komposisi kurma, air dan gula, 5 sampel mengandung komposisi kurma, air dan tambahan simplisia lainnya seperti madu, propolis habaitussauda dan angkak, 2 sampel tidak memiliki nomor registrasi dari BPOM, 9 sampel memiliki nomor registrasi dari BPOM, 7 sampel memiliki expired date tahun 2018,1 sampel memiliki expired date tahun 2017, 2 sampel memiliki expired date tahun 2019, dan 1 sampel memiliki expired date tahun 2020.

\section{Pemeriksaan Sampel Berdasarkan Kriteria Penelitian}

Pemeriksaan sampel dilakukan berdasarkan kriteria inklusi. Sampel dikelompokkan dalam sari buah kurma yang mengandung kurma, air dan gula, sari buah kurma mencantumkan nomor registrasi P-IRT dari BPOM dan sari buah kurma dengan expired date tahun 2018.

\section{Uji kandungan kimia sari buah kurma \\ Identifikasi Fenol}

Ekstrak di masukkan ke dalam tabung reaksi kemudian ke dalam tabung reaksi ditambahkan 2 tetes $\mathrm{FeCl}_{3} 5 \%$ jika terbentuk warna kehijauan, merah, ungu dan hitam menunjukkan adanya fenol. (9)

\section{Identifikasi Flavonoid}

Uapkan hingga kering $1 \mathrm{ml}$ larutan percobaan, sisa dilarutkan dalam $1 \mathrm{ml}$ etanol (95\%) P ; tambahkan 0,1 g serbuk magnesium $\mathrm{P}$ dan 10 tetes asam klorida pekat $\mathrm{P}$, jika terjadi warna merah jingga sampai merah ungu, menunjukkan adanya flavonoid. Jika terjadi warna kuning jingga menunjukkan adanya flavon, kalkon, dan auron. $(9,10)$

\section{Identifikasi Alkaloid}

Ekstrak dimasukkan ke dalam tabung reaksi, kemudian ditambahkan beberapa tetes pereaksi Dragendorff dan pereaksi Mayer pada tabung yang lain. Reaksi positif jika pada penambahan Dragendorff terbentuk endapan merah bata atau endapan putih pada penambahan pereaksi Mayer. $(9,10)$ 


\section{Identifikasi Saponin}

Sampel cairan diencerkan $1 \mathrm{ml}$ dengan $10 \mathrm{ml}$ air,dikocok kuat kuat selama 10 menit kemudian tambahkan air panas, dinginkan dan kemudian kocok kuat kuat selama 10 detik. Akan terbentuk buih yang mantap selama tidak kurang dari 10 menit, setinggi 1 $\mathrm{cm}$ sampai $10 \mathrm{~cm}$. Pada penambahan 1 tetes asam klorida $2 \mathrm{~N}$, buih tidak hilang. $(9,10)$

\section{Pengujian kadar fenolik total sampel uji dengan metode Folin Ciocalteu.}

\section{Pembuatan Larutan Induk Asam Galat}

Ditimbang 0,50 g asam galat tambahkan $1 \mathrm{ml}$ etanol $96 \%$ tambahkan aquadest sampai 50 $\mathrm{ml}$, sehingga diperoleh konsentrasi 1000ppm. Dari larutan dibuat konsentrasi 100, 125, 150, 175, 200 ppm asam galat. Dari masingmasing konsentrasi diatas dipipet $0,2 \mathrm{ml}$ tambah 15,8 ml aquadest ditambah $1 \mathrm{ml}$ Reagen Folin Ciocalteu kocok. Diamkan selama 8 menit tambah $3 \mathrm{ml}$ larutan $\mathrm{Na}_{2} \mathrm{CO}_{3} 10 \%$ kocok homogen. Diamkan selama 1 jam pada suhu kamar. Ukur serapan pada panjang gelombang serapan maksimum,lalu buat kurva kalibrasinya hubungan antara konsentrasi asam galat (mgGAE/g sampel). (11)

\section{Penentuan Kandungan Fenol Total dengan Metode Folin -Ciocalteu}

Ditimbang 0,1 gram sampel kemudian dilarutkan sampai $10 \mathrm{ml}$ dengan aquadest. Dari larutan tersebut di pipet $1 \mathrm{ml}$ kemudian ditambahkan sampai $10 \mathrm{ml}$ dengan aquadest. Dipipet $0,2 \mathrm{ml}$ larutan sampel dari masing masing konsentrasi dan tambahkan 15,8 ml aquadest tambahkan $1 \mathrm{ml}$ reagen Folin Ciocalteu kocok. Diamkan selama 8 menit kemudian ditambahkan $3 \mathrm{ml} \mathrm{Na} \mathrm{CO}_{3} \quad 10 \%$ kedalam campuran, diamkan larutan selama 1 jam pada suhu kamar. Diukur serapannya dengan spektrofotometer UV-Vis pada panjang gelombang serapan maksimum yang akan memberikan komplek biru. Lakukan 3 kali pengulangan sehingga kadar fenolik total yang diperoleh hasilnya didapat sebagai mg GAE/g sampel. (11).

\section{Pengujian kemampuan antioksidan sampel uji dengan Spektrofotmetri}

\section{Pembuatan Larutan Pereaksi DPPH}

Ditimbang sebanyak 19,86 mg DPPH dan dilarutkan dengan metanol p.a di dalam labu sampai $50 \mathrm{ml}$ sehingga diperoleh larutan dengan konsentrasi $1 \mathrm{mM}$. Dari konsentrasi $1 \mathrm{mM}$ dipipet sebanyak $5 \mathrm{ml}$ kemudian ditambahkan metanol p.a di dalam labu ukur $50 \mathrm{ml}$ sehingga diperoleh larutan dengan konsentrasi $0,1 \mathrm{mM}$. Larutan DPPH $0,1 \mathrm{mM}$ dalam metanol p.a adalah larutan yang akan digunakan sampai uji aktivitas antioksidan selesai.(4)

\section{Pembuatan Larutan Blanko}

Dipipet sebanyak $2 \mathrm{ml}$ larutan DPPH 0,1 mM dan ditambahkan $2 \mathrm{ml}$ metanol p.a.(4)

\section{Penentuan Aktivitas Antioksidan}

Ditimbang sampel sebanyak $80 \mathrm{mg}$, kemudian dilarutkan metanol p.a dalam labu ukur ad $10 \mathrm{ml}$, maka didapatkan konsentrasi 8000 ppm. Untuk penentuan aktivitas antioksidan masing-masing konsentrasi dipipet sebanyak $2 \mathrm{ml}$ larutan sampel dan masukan ke dalam vial, kemudian tambahkan 2 ml larutan DPPH 0,1mM. Campuran dihomogenkan dan dibiarkan selama 5, 30 dan 60 menit ditempat gelap, serapan diukur dengan spektrofotometer UV - Vis pada panjang gelombang maksimum pada menit ke 5, 30 dan 60. Sebagai pembanding digunakan asam askorbat 8 ppm dengan perlakuan yang sama dengan sampel uji. (12) 
Tabel 1. Hasil Uji Kandungan Kimia Jus Buah Kurma dan Sampel

\begin{tabular}{|c|c|c|c|c|c|c|}
\hline $\mathrm{NO}$ & Pemeriksaan & Metode & Pengamatan & $\begin{array}{l}\text { Hasil } \\
\text { Jus } \\
\text { Kurma }\end{array}$ & $\begin{array}{l}\text { Sampel } \\
X\end{array}$ & $\begin{array}{l}\text { Sampel } \\
\text { Y }\end{array}$ \\
\hline 1 & Fenol & $\mathrm{FeCl}_{3} 5 \%$ & $\begin{array}{l}\text { Warna hijau } \\
\text { kehitaman }\end{array}$ & + & + & + \\
\hline 2 & Flavonoid & $\begin{array}{l}\mathrm{Mg} \text { serbuk } \\
\mathrm{HCl}\end{array}$ & $\begin{array}{l}\text { Warna merah } \\
\text { kecoklatan }\end{array}$ & + & + & + \\
\hline 3 & Alkaloid & $\begin{array}{l}\text { Pereaksi } \\
\text { Dragendroff } \\
\text { Pereaksi } \\
\text { Mayer }\end{array}$ & $\begin{array}{l}\text { Dragendroff: } \\
\text { Endapan } \\
\text { merah } \\
\text { kecoklatan } \\
\text { Mayer: } \\
\text { Endapan Putih }\end{array}$ & - & - & - \\
\hline 4 & Saponin & $\begin{array}{l}\text { Aquadest } \\
\text { panas }\end{array}$ & $\begin{array}{l}\text { Terbentuk } \\
\text { buih }\end{array}$ & + & + & + \\
\hline
\end{tabular}

\section{Penentuan Persen Peredaman}

Kemampuan antioksidan diukur sebagai penurunan serapan larutan DPPH akibat adanya penambahan sampel uji. Nilai resapan larutan DPPH sebelum dan sesudah penambahan sampel uji tersebut dihitung sebagai persen peredaman. Perhitungan kapasitas antiradikal bebas DPPH sebagai persen peredaman absorban pada puncak 515 nm menggunakan perhitungan sebagai berikut (4) :

\section{$\%$ peredaman DPPH =}

$\frac{\text { A hitung DPPH-A hitung bahan uji }}{\text { A hitung DPPH }} \times 100 \%$

\section{HASIL DAN PEMBAHASAN}

\section{Uji Kandungan Kimia Jus Buah Kurma dan Sampel}

Dari hasil identifikasi kualitatif (Tabel 1), semua sampel uji positif mengandung senyawa fenol, flavonoid dan saponin. Ini menunjukkan bahwa ketiga sampel masih mengandung kandungan fenolik salah satunya flavonoid yang bertindak sebagai antioksidan alami, karena mengandung gugus hidroksil yang mampu menangkap radikal bebas.

\section{Analisis Peredaman Radikal Bebas DPPH Oleh Sampel Uji}

Analisis peredaman radikal bebas DPPH oleh sampel uji dapat diperoleh dengan terlebih dahulu menentukan $\mathrm{A}_{0}$ (absorbansi blanko) dari hasil data pengukuran absorbansi blanko pada panjang gelombang $517 \mathrm{~nm}$. Dari analisis yang terlah dilakukan, diperoleh nilai persen peredaman di waktu 5 menit, 30 menit dan 60 menit. Nilai persen peredaman radikal bebas DPPH oleh sampel uji dapat terlihat pada Tabel 2.

Pemeriksaan aktivitas antioksidan mengunakan metode DPPH secara spektrofotometri dilakukan dengan mereaksikan sampel dan DPPH pada panjang gelombang $517 \mathrm{~nm}$. Konsentrasi DPPH yang dipilih adalah $0,1 \mathrm{mM}$ atau $100 \mu \mathrm{M}$. (4) Metode DPPH dipilih karena sederhana, cepat dan peka serta hanya membutuhkan sedikit sampel. (13) Aktivitas antioksidan diukur dengan menghitung jumlah pengurangan intensitas warna ungu DPPH yang sebanding dengan penambahan konsentrasi larutan uji. 
Tabel 2. Hasil Analisis Peredaman Radikal Bebas DPPH Oleh Sampel Uji Jus Buah Kurma, Sampel X dan Sampel Y konsentrasi 8000 ppm

\begin{tabular}{ccccccc}
\hline Menit & Sampel & As1 & As2 & As3 & $\begin{array}{c}\text { As Rata } \\
\text { Rata }\end{array}$ & \% Inhibisi \\
\hline Ke - 5 & Jus & 0,0937 & 0,0952 & 0,0895 & 0,0895 & $83,65 \%$ \\
& Sampel X & 0,1398 & 0,1366 & 0,1378 & 0,1378 & $75,68 \%$ \\
& Sampel Y & 0,1629 & 0,1615 & 0,1621 & 0,1621 & $71,45 \%$ \\
Ke - 30 & Jus & 0,0481 & 0,0476 & 0,0483 & 0,0480 & $91,54 \%$ \\
& Sampel X & 0,0747 & 0,0738 & 0,0742 & 0,0742 & $86,93 \%$ \\
& Sampel Y & 0,0577 & 0,0568 & 0,0571 & 0,0572 & $89,92 \%$ \\
Ke - 60 & & & & & & \\
& Jus & 0,0847 & 0,0838 & 0,0843 & 0,0843 & $85,17 \%$ \\
& Sampel X & 0,0751 & 0,0763 & 0,0765 & 0,0765 & $86,63 \%$ \\
Keterangan* : As = Absorbansi. Semakin kecil nilai absorbansi maka nilai persen inhibisi akan semakin besar.
\end{tabular}

Peredaman tersebut dihasilkan oleh bereaksinya molekul difenil pikril hidrazil dengan atom hidrogen yang dilepaskan oleh satu molekul komponen sampel, sehingga terbentuknya senyawa difenil pikril hidrazin dan menyebabkan terjadinya peluruhan warna DPPH dari ungu menjadi kuning. (13)

Dalam menentukan operating time, penelitian ini mengacu pada rekomendasi literatur teori aktivitas antioksidan yaitu di inkubasi kemudian di ukur absorbansinya pada menit ke 5, menit ke 30 dan menit 60 . (12) Waktu tersebut dipilih untuk melihat perbedaan persen hambatan radikal bebas DPPH oleh sampel. Waktu tersebut dipilih juga untuk menyeragamkan waktu operating time ketiga sampel, sehingga perbedaan nilai penghambatan radikal bebas oleh DPPH lebih terlihat.

Dari data pengukuran (\%) persen peredaman, dapat dijabarkan bahwa penyerapan terbesar dari hambatan radikal bebas DPPH oleh sampel uji ada pada menit ke 30. Hal ini disebabkan karena menit ke 30 merupakan waktu terbaik dimana sampel uji sudah cukup reaktif untuk menyerap radikal bebas DPPH. (4)

Nilai aktivitas antioksidan pada sampel jus buah kurma dan sari buah kurma dapat dilihat dari hasil perhitungan persentase

Tabel 3. Hasil Analisis Peredaman Radikal Bebas DPPH Oleh Vitamin C di 8 ppm

\begin{tabular}{ccccccc}
\hline Menit & Sampel & As1 & As2 & As3 & $\begin{array}{c}\text { As Rata } \\
\text { Rata }\end{array}$ & $\begin{array}{c}\% \\
\text { Inhibisi }\end{array}$ \\
\hline Ke -5 & Vitamin C & 0,0534 & 0,0521 & 0,0552 & 0,0535 & $90,57 \%$ \\
Ke -30 & Vitamin C & 0,0219 & 0,0210 & 0,0224 & 0,0217 & $96,17 \%$ \\
Ke -60 & Vitamin C & 0,0342 & 0,0338 & 0,0345 & 0,0345 & $93,99 \%$ \\
\hline \multicolumn{2}{l}{ Keterangan* : As = Absorbansi } & & & &
\end{tabular}


Tabel 4. Hasil Absorbansi Standar Asam Galat Pada Panjang Gelombang 774 nm

\begin{tabular}{ccccc}
\hline Konsentrasi & As 1 & As 2 & As 3 & As Rata-Rata \\
\hline $100 \mathrm{ppm}$ & 0,1268 & 0,1271 & 0,1265 & 0,1268 \\
$125 \mathrm{ppm}$ & 0,1475 & 0,1482 & 0,1471 & 0,1476 \\
$150 \mathrm{ppm}$ & 0,1758 & 0,1768 & 0,1763 & 0,1763 \\
$175 \mathrm{ppm}$ & 0,2002 & 0,2001 & 0,1949 & 0,1984 \\
$200 \mathrm{ppm}$ & 0,2150 & 0,2151 & 0,2143 & 0,2148 \\
\hline
\end{tabular}

Keterangan $*$ : As $=$ Absorbansi

peredaman DPPH (Tabel 2 dan 3) menunjukkan bahwa persentase peredaman radikal bebas DPPH pada menit-30 jus buah kurma yaitu 91,54\% , sampel X 86,93\% sedangkan sampel Y 89,92\% sehingga persentase peredaman radikal bebas DPPH yang paling besar terdapat pada jus buah kurma.Hasil diatas menunjukkan bahwa sari buah kurma dari produsen yang berbeda makaaktivitas antioksidannya pun berbeda pula. Perbedaan ini disebabkan karena sumber buah kurma, konsentrasi buah kurma dan air pada kedua sampel sari buah kurma tersebut berbeda sehingga komposisi senyawanya juga berbeda.(5) Sementara pada jus buah kurma terlihat paling besar karena jus buah kurma dibuat segar dari buah kurma dan tambahan air, dimana air bertindak sebagai pelarut polar yang mampu untuk menarik senyawa flavonoid. (13) Selain itu, nilai ini juga menunjukkan bahwa pada jus buah kurma,sampel X dan sampel Y sari buah kurma persentase peredaman radikal bebas DPPH berada di atas $50 \%$ berarti pada ketiga sampel tersebut aktif meredam radikal bebas dan berpotensi sebagai senyawa antioksidan. Dimana suatu bahan dikatakan aktif sebagai antioksidan bila persentase peredamannya lebih dari atau sama dengan 50\%. (12)

Untuk uji aktivitas antioksidan ini digunakan baku Vitamin $\mathrm{C}$ sebagai kontrol positif untuk melihat persen peredaman radikal bebas DPPH. Didapatkan persen peredaman vitamin $\mathrm{C}$ di menit ke 30 untuk radikal bebas DPPH adalah 96,17\% dengan konsentrasi Vitamin C 8 ppm. Hal ini menunjukkan bahwa aktivitas peredaman radikal bebas DPPH oleh Vitamin $\mathrm{C}$ lebih besar jika dibandingkan dengan ketiga sampel uji baik jus buah kurma, sampel $X$ dan sampel Y sebagaimana ditunjukkan Tabel 5. Untuk pengujian kadar fenolik total (Tabel 4 dan 5) dimulai dengan penentuan panjang gelombang maksimum oleh larutan standar

Tabel 5. Absorbansi Sampel Uji Kandungan Total Fenolik

\begin{tabular}{cccccc}
\hline Sampel & As 1 & As 2 & As 3 & $\begin{array}{c}\text { As Rata } \\
\text { Rata }\end{array}$ & $\begin{array}{c}\text { Total Fenolik } \\
\text { mgGAE/g sampel }\end{array}$ \\
\hline Jus & 0,3159 & 0,3159 & 0,3154 & 0,3157 & 9,25 \\
Sampel X & 0,1971 & 0,1972 & 0,1969 & 0,1970 & 4,13 \\
Sampel Y & 0,1985 & 0,1989 & 0,1991 & 0,1988 & 4,28 \\
\hline
\end{tabular}

Keterangan : As = Absorbansi. Semakin besar nilai Absorbansi maka nilai total Fenolik juga semakin besar. Nilai total Fenolik terbesar ada pada Sampel Jus Buah Kurma. 
asam galat di konsentrasi 200 ppm dihasilkan puncak serapan pada panjang gelombang 774 $\mathrm{nm}$, sehingga panjang gelombang maksimum tersebut digunakan selanjutnya untuk penentuan kadar total senyawa fenolat.

Hasil dari pengukuran absorbansi sejumlah standar asam galat dengan seri konsentrasi 100 - 200 ppm pada panjang gelombang $774 \mathrm{~nm}$ diperoleh persamaan regresi $\mathrm{y}=0,0227 \mathrm{x}+0,1047$ dengan $\mathrm{r}=$ 0,9925, nilai ini menunjukkan bahwa absorbansi dengan konsentrasi memberikan hubungan yang linier. Penentuan kadar total senyawa fenolat pada sampel jus buah kurma dan sampel sari buah kurma ditentukan dengan memplotkan absorbansi sampel pada persamaan regresi linear kurva kalibrasi standar asam galat. Data absorbansi serta kadar fenolik total sampel uji dipaparkan pada tabel 4.5, dimana menunjukkan bahwa kadar total senyawa fenolat pada jus buah kurma lebih tinggi dibandingkan dengan Sampel X dan Sampel Y yaitu 9,25 mgGAE/g sampel. Sedangan sari buah kurma Sampel X menunjukkan angka 4,13 mgGAE/g sampel dan sari buah kurma Sampel $Y$ 4,28 mgGAE/g sampel. Hal ini menunjukkan bahwa pada jus buah kurma menghasilkan kadar total senyawa fenolik yang lebih tinggi karena jus buah kurma tidak mengalami proses pembuatan dan penambahan zat lainnya seperti sampel sari buah kurma yang prosesnya dijelaskan diatas.

Hubungan berdasarkan hasil kadar fenolik total jus buah kurma, sari buah kurma Sampel X dan Sampel Y dapat dilihat bahwa adanya hubungan yang linier dengan aktivitas antiradikal bebasnya. Dimana, kadar total senyawa fenolat yang tertinggi terdapat pada jus buah kurma yang juga memiliki nilai aktivitas antioksidan bebas yang tinggi. Sementara kadar fenolik terendah dimiliki oleh Sampel $\mathrm{X}$ begitu pun aktivitas antioksidannya.

Namun, jika dilihat dari nilai fenolik total ketiga sampel masih tergolong kecil, sehingga diduga persen peredaman yang dihasilkan oleh Jus Buah Kurma, Sampel X dan Sampel Y sari buah kurma tidak hanya dari kandungan fenolik nya saja.

\section{SIMPULAN DAN SARAN}

Uji kualitatif pada jus buah kurma dan sari buah kurma Sampel X dan Sampel Y menunjukkan positif adanya senyawa fenolat. Hasil persen peredaman sampel uji terbaik dalam meredam radikal bebas DPPH adalah pada menit ke 30. Jus Buah Kurma memiliki nilai persen peredaman yang paling tinggi dibanding dengan Sampel X dan Sampel Y sari buah kurma.Untuk kontrol positif Vitamin C dapat menghambat 96,17\% DPPH, nilai ini lebih tinggi jika dibandingan dengan Jus Buah Kurma, Sampel X dan Sampel Y. Jus Buah Kurma, Sampel X dan Sampel Y sari buah kurma memiliki potensi sebagai senyawa antioksidan jika dikonsumsi dalam konsentrasi yang tinggi sehingga baik untuk masyarakat.

Dapat dilakukan penelitian lebih lanjut senyawa fenolat yang terdapat pada buah kurma dan sari buah kurma. Dapat dilakukan penelitian untuk aktivitas antioksidan dan total fenol pada ekstraksi buah kurma dengan pelarut yang polar. Dapat dilakukan penelitian lebih lanjut menggunakan variasi konsentrasi larutan sehingga range hasil persen peredaman dan total fenolik lebih terlihat.

\section{DAFTAR PUSTAKA}

1. Winarsi H. Antioksidan alami dan radikal bebas, potensi dan aplikasinya dalam kesehatan. Yogyakarta; Kanisius; 2007.

2. Amirudin Akhlis Fahlevi. Uji Aktivitas Antioksidan Ekstrak Etanol Buah Kurma Ajwah (Phoenix dactylifera) Pada Mencit Putih Jantan yang Diinduksi Parasetamol. [Skripsi]. Surakarta ; Universitas Muhammadiyah Surakarta ; 2015.

3. Tamat $\mathrm{R}$ Swasono et all. Aktivitas Antioksidan dan Toksisitas Senyawa Bioaktif dari Ekstrak Rumput Laut Hijau Ulva reticulata Forsskal. Jakarta ; Jurnal Kefarmasian Indonesia; 2007. 
4. Molyneux Philip. The Use of the Stable Free Radical Diphenylpicryl-hydrazyl (DPPH) for Estimating Antioxidant Activity. Songklanakarin J. Sci. Technology. UK ; 2014.

5. Al-Mamary Mohammed et all. The In Vitro Antioxidant Activity of Different Types of Palm Dates (Phoenix dactylifera L.) syrups. Arabian Journal Chemistry. Arab Saudi ; King Saud University ; 2010.

6. Anonim, Sari Kurma, Antara Syiar Islam Dan Peluang Bisnis, http://www.antaranews.com/print/117566 /sari-kurma-antara-syiar-islam-danpeluang-bisnis. Diakses pada Kamis 15 Juni 2017 Pukul 20.35 WIB.

7. Yuliantari Ni Wayan Ayuk. Pengaruh Suhu dan Waktu Ekstraksi Terhadap Kandungan Flavonoid dan Aktivitas Antioksidan Daun Sirsak (Annona muricata L) Menggunakan Ultrasonik. Bali ; Universitas Udayana Fakultas Teknologi Pertanian ; 2017. [Skripsi].

8. Keskin-Šašić et all. Total Phenolic Content and Antioxidant Activity of Fruit Juice. Bulletin of the Chemists and Technologists of Bosnia and Herzegovina ; 2012.
9. Harbone JB. Metode fitokimia, penuntun cara modern menganalisa tumbuhan, Terjemahan K. Padmawinata, Edisi II. Bandung: ITB Press; 1987.

10. Departemen Kesehatan Republik Indonesia. Materi medika Indonesia Jilid V. Jakarta. Departemen Kesehatan Republik Indonesia; 1989.

11. Pratiwi Putri, Meiny Suzery, Bambang Cahyono. Total Fenolat dan Flavonoid dari Ekstrak dan Fraksi Daun Kumis Kucing (Orthosipon staminues L). Semarang : Universitas Diponegoro Jurusan Kimia FMIPA ; 2010.

12. Ratnayani Ketut et all. Kadar Total Senyawa Fenolat Pada Madu Randu dan Madu Kelengkeng Serta Uji Aktivitas Antiradikal Bebas dengan Metode DPPH (Difenilpikril Hidrazil). Bali ; Universitas Udayana Fakultas Kimia FMIPA ; 2012.

13. Nabillah Deya Adibi. Aktivitas Antioksidan Ekstrak EtanolDaun Sirsak (Annona muricata L.) Menggunakan Metode DPPH (1,1-difenil-2pikrilhidrazil). Jakarta ; Poltekkes Kemenkes Jakarta II Jurusan Farmasi ; 2016. [Karya Tulis Ilmiah] 